\title{
Pengendalian Kamera berdasarkan Deteksi Posisi Manusia Bergerak Jatuh berbasis Multi Sensor Accelerometer dan Gyroscope
}

\author{
RAHMI AGUS MELITA, SUSETYO BAGAS BHASKORO, RUMINTO SUBEKTI \\ Politeknik Manufaktur Bandung \\ Email: rahmiagusmelita@gmail.com
}

Received 1 April 2018 | Revised 10 Mei 2018 | Accepted 31 Mei 2018

\begin{abstract}
ABSTRAK
Penelitian ini menyajikan pengembangan sistem surveillans berbasis multisensor secara portable dengan memberikan peringatan terkait aktifitas yang tidak biasa. Sistem menginformasikan pengguna atau pengasuh melalui email ketika mendeteksi aktifitas yang abnormal, seperti gerakan jatuh (lansia atau anakanak). Penelitian ini menggunakan multisensor antara lain accelerometer, gyroscope, dan menambahkan sensor kamera untuk membuat informasi lebih akurat. Evaluasi dibagi menjadi dua kategori. kategori pertama adalah deteksi jatuh manusia, dan kategori kedua adalah menangkap gambar. Hasil evaluasi mendeteksi gerakan jatuh adalah accuracy sebesar $88 \%$, recall $88 \%$, specificity $88 \%$, dan precision 93\%. Selain itu, hasil evaluasi pengambilan gambar adalah accuracy $86 \%$ dengan ketepatan pergerakan kamera ke arah objek sebesar $51 \%$.
\end{abstract}

Kata kunci: bergerak jatuh, kamera, internet of things, accelerometer, gyroscope, fuzzy logic.

\begin{abstract}
This research presents the development of multi-sensor based portable surveilance system with intrusion alert notification. The system will notify the user or caregiver by email immediately when an abnormal activity is detected, such as falling motion (elderly or children). This research using multisensor there are accelerometer, gyroscope, and adding camera sensor to make information more accurate. The evaluation divided into two categories. first category is human falling detection, and second category is capturing image. The result of falling detection are $88 \%$ for accuracy, $88 \%$ for recall, $88 \%$ for specificity, and precision is $93 \%$. The result of capturing image are $86 \%$ for accuracy $86 \%$, with camera motor movement precision is $51 \%$.
\end{abstract}

Keywords: falling motion, camera, internet of things, accelerometer, gyroscope, fuzzy logic. 


\section{PENDAHULUAN}

Jatuh merupakan kejadian yang sering terjadi pada usia lanjut yang telah mengalami penurunan daya tahan tubuh, anak-anak yang sedang mengalami perkembangan, dan orang yang memiliki gangguan kesehatan. Fakta terkait dengan jatuh dari World Health Organization (WHO) menyebutkan bahwa jatuh merupakan penyebab kematian kedua terbesar di dunia, yaitu sebesar 424.000 kali per tahun. Besarnya angka kematian akibat jatuh ini disebabkan oleh beberapa faktor, antara lain lemahnya kemampuan untuk berdiri kembali, tidak adanya pertolongan pertama, korban kesulitan menghubungi keluarga. Oleh karena itu, penelitian yang terkait dengan body sensor network berkembang dan diperuntukkan untuk monitoring kesehatan (N, Z, Gravina, \& Fortino, 2017). Penelitian monitoring kesehatan salah satunya adalah melakukan pengawasan terhadap manusia secara jarak jauh yang memiliki potensi jatuh cukup besar. Sistem pengawasan ini bekerja secara otomatis, terus menerus dan memberikan reminder melalui email apabila terdapat perubahan kondisi dan posisi gerak seseorang yang dimonitor.

Penelitian Dedy (Nur Arifin, Wibisono, \& Adi Pratomo, 2013) dan Mardi (Hardjianto, Rony, \& Trengginas, 2016) memanfaatkan sensor accelerometer dan gyroscope yang terdapat pada smartphone uzntzuk mendetekszi gerakan jatuh. Penelitian Tang (Tang, Ong, \& Ahmad, 2015) hanya memanfaatkzan sensor accelerometer yang juga terdapat pada smartphone. Saat jatuh terdeteksi, alarm akan berbunyi dan emergency SMS pun dikirimkan. sKendala terkait dengan jaminan informasi dilengkapi di penelitian Wasis (Wasis, Kurniawan, \& Muttaqin, 2015) menggunakan sensor accelerometser yang dikemas dalam sebuah sabuk, serta tiga buah kamera yang dipasang pada tiga ruangan yang berbeda. Selain itu, aplikasi Android digunakan sebagai notifikasi. Saat jatuh terdeteksi, kamera akan mengambil gambar ruangan, kemudian notifikasi akan dikirimkan kepada smartphone keluarga.

Dari penelitian di atas, dapat disimpulkan bahwa pemanfaatan sensor accelerometer dan gyroscope serta penggunaan kamera sebagai sistem pendeteksi jatuh akan menghasilkan hasil yang lebih baik. Penelitian ini membahas tentang sebuah sistem yang memanfaatkan sensor dengan melakukan modifikasi sinyal accelerometer dan gyroscope untuk mendeteksi jatuh dan mengontrol pergerakan motor kamera serta mengambil gambar objek berdasarkan posisi koordinat terdeteksi jatuh. Sistem ini juga memanfaatkan email sebagai notifikasi saat jatuh terdeteksi.

\section{PERANCANGAN SISTEM}

Perancangan sistem pengendalian kamera berdasarkan deteksi posisi manusia bergerak jatuh berbasis sensor accelerometer dan gyroscope seperti pada Gambar 1 berikut.

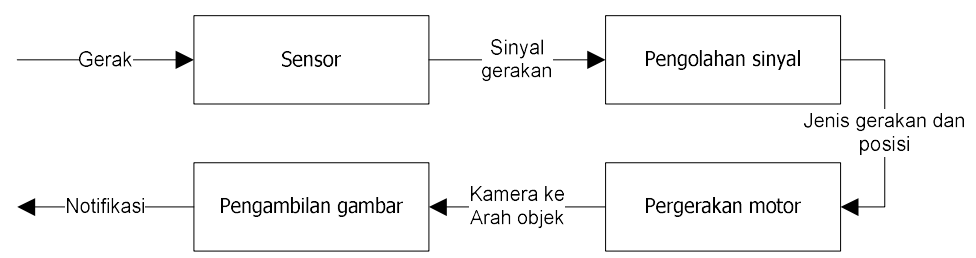

Gambar 1. Blok Diagram Sistem 


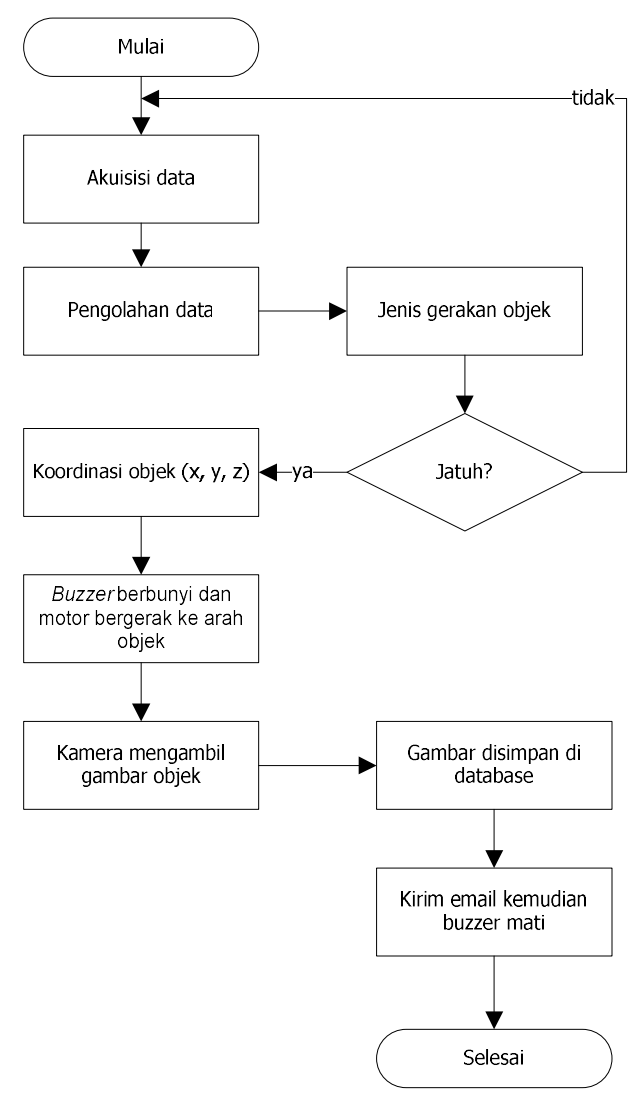

Gambar 2. Diagram alir sistem
Berdasarkan Gambar 1, sistem yang dikembangkan di penelitian ini membutuhkan perangkat keras dan perangkat lunak yang digunakan untuk melakukan pengambilan (akuisisi), pengolahan, dan pengiriman data, menggerakkan kamera dan mengambil gambar objek. Pembahasan lebih lengkap terkait dengan perangkat lunak dan perangkat keras dibagi menjadi beberapa bagian yaitu akuisisi data gerakan objek, base station (pengolahan data), dan bagian penggerak kamera.

Sensor accelerometer dan gyroscope adalah sensor yang sering digunakan untuk menentukan jenis gerakan (Hidayatno \& Wahyudi, 2011) dan posisi sudut (Perkasa \& Rachmat, 2017). Cara kerja dari sistem ini dapat dilihat pada Gambar 2.

Berdasarkan diagram alir Gambar 2, keluaran dari kedua sensor sebelumnya akan dimanfaatkan untuk sensor lainnya yaitu kamera. Terlihat bahwa kamera akan bergerak ke arah objek apabila objek tersebut terdeteksi jatuh. Setelah kamera diarahkan ke objek, kamera akan mengambil gambar objek dan selanjutnya sistem akan mengirimkan notifikasi.

\subsection{Akuisisi data gerakan objek}

Gerakan yang dilakukan oleh objek menghasilkan perubahan statis dan dinamis. Perubahan ini menjadi parameter penting dalam pemilihan sensor untuk mengakuisisi data gerakan objek. Beberapa alternatif pilihan sensor pendeteksi gerakan dapat dilihat pada Tabel 1 seperti berikut.

Tabel 1. Alternatif Pilihan Sensor

\begin{tabular}{|c|c|c|c|}
\hline Nama Sensor & Accelerometer & Gyroscope & PIR (Passive Infra Red) \\
\hline Tampilan & $8-\frac{1}{2}$ & An & \\
\hline $\begin{array}{c}\text { Statis } \\
\text { Dinamis }\end{array}$ & $\begin{array}{l}\sqrt{ } \\
\sqrt{ }\end{array}$ & $\begin{array}{l}\sqrt{ } \\
\sqrt{ }\end{array}$ & $\begin{array}{l}x \\
\sqrt{ }\end{array}$ \\
\hline Orientasi & 3-axis & 3-axis & - \\
\hline Output & Analog & Digital & Digital \\
\hline Dimensi $(\mathrm{mm})$ & $21 \times 16$ & $23 \times 23$ & $32 \times 24$ \\
\hline Input voltage (V) & $3-5$ & $3.6-6.5$ & $4.5-20$ \\
\hline Kesesuaian & 4 & 4 & 2 \\
\hline
\end{tabular}

Berdasarkan tabel di atas dapat dilihat bahwa sensor yang sesuai untuk pendeteksi gerakan di sistem ini adalah sensor accelerometer dan gyroscope. Sensor tersebut dapat mendeteksi perubahan gerakan statis dan dinamis. Kedua sensor ini dapat mendeteksi gerakan berdasarkan percepatan dan orientasi yang terjadi saat objek bergerak. Hasil deteksi orientasi sensor accelerometer cenderung patah-patah, sedangkan sensor gyroscope 
menghasilkan deteksi orientasi yang lebih halus. Oleh sebab itu, untuk menghasilkan pendeteksian yang lebih optimal kedua sensor ini perlu dikombinasikan. Modul sensor yang digunakan pada sistem ini adalah modul MPU 92/65.

Data hasil pembacaan sensor kemudian diolah oleh sebuah mikrokontroler, Arduino Pro Mini, kemudian dikirimkan ke base station menggunakan modul Bluetooth HC-05. Semua komponen ini kemudian dikemas menjadi sebuah sabuk yang akan digunakan oleh objek. Komponen penyusun sabuk ini dapat dilihat pada Gambar 3, sedangkan skematik rangkaiannya dapat dilihat pada Gambar 4.

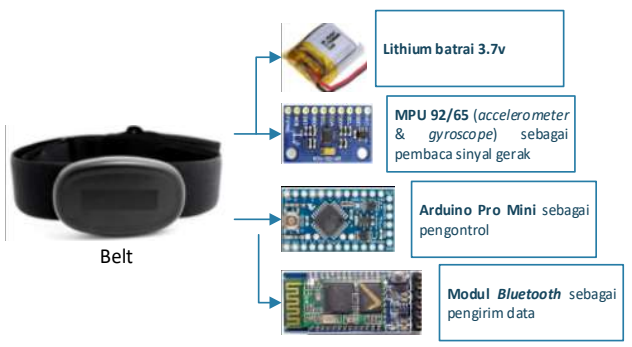

Gambar 3. Komponen Penyusun Sabuk

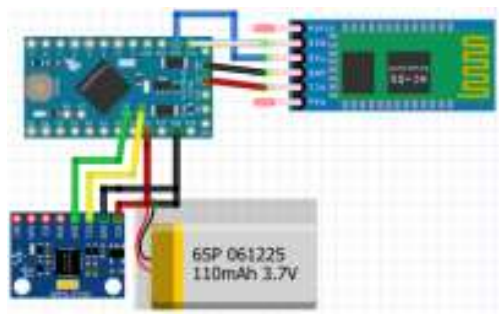

Gambar 4. Skematik Rangkaian Akuisisi Data Gerakkan

\subsection{Base station}

Perangkat keras yang digunakan sebagai base station adalah PC. Base station merupakan bagian utama dari sistem yang berfungsi untuk mengolah data yang dikirimkan dari sensor, sehingga dapat menentukan status objek dan mengendalikan kamera ke arah objek. Base station juga digunakan sebagai interface sistem berupa grafik dan gambar. Perangkat lunak yang digunakan pada base station adalah LabView.

\subsection{Penggerak kamera}

Kamera yang digunakan pada sistem ini adalah kamera dengan lensa standar seperti di Gambar 5, dengan kemampuan bekerja 60 derajat. Selain itu kamera ini dapat menghasilkan kualitas gambar yang cukup jelas (320 x 240 px). Kamera akan bergerak ke arah objek yang terdeteksi jatuh. Penggerak kamera ini adalah motor servo seperti di Gambar 6. Motor servo tersebut memiliki kecepatan yang cukup tinggi, selain itu memiliki metode kontrol close loop yang meminimalisir kesalahan dalam pergerakannya. Motor ini digerakkan oleh mikrokontroler, yaitu arduino nano. Skematik rangkaian penggerak kamera dapat dilihat pada Gambar 7.

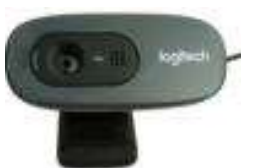

Gambar 5. Kamera Logitech C270

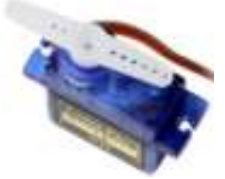

Gambar 6. Motor Servo

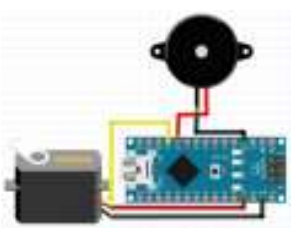

Gambar 7. Skematik Rangkaian Penggerak Kamera

Berdasarkan aliran sistem Gambar 2, keseluruhan sistem saling berhubungan secara sistematis. Keterhubungan seluruh sistem terlihat di Gambar 8. 


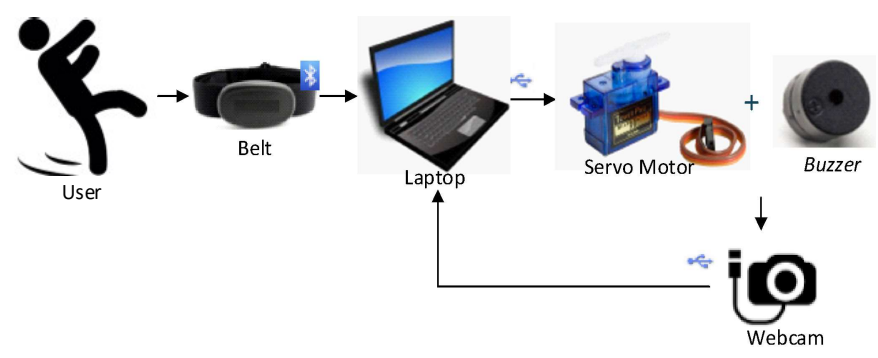

Gambar 8. Gambaran Umum Sistem

\section{PENGUJIAN DAN ANALISIS}

\subsection{Akuisisi data gerak}

Pada subsistem ini data dari sensor diolah menjadi 4 jenis gerakan dan diolah untuk mendeteksi posisi objek. Pengolahan data menjadi 4 jenis gerakan dilakukan dengan metode fuzzy logic. Sistem fuzzy yang digunakan adalah Multiple Input - Single Output (MISO), karena memiliki dua buah input yaitu percepatan dan kecepatan sudut, serta memiliki satu buah output yaitu jenis gerakan objek. Himpunan fuzzy yang digunakan didapatkan dari analisa nilai perubahan percepatan dan kecepatan sudut yang dihasilkan oleh pergerakan objek setiap $50 \mathrm{~ms}$.

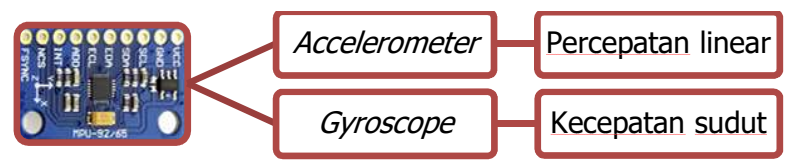

Gambar 9. Akuisisi Data Sensor

Nilai rata-rata sinyal yang didapatkan dijadikan sebagai nilai threshold untuk setiap jenis gerakan.
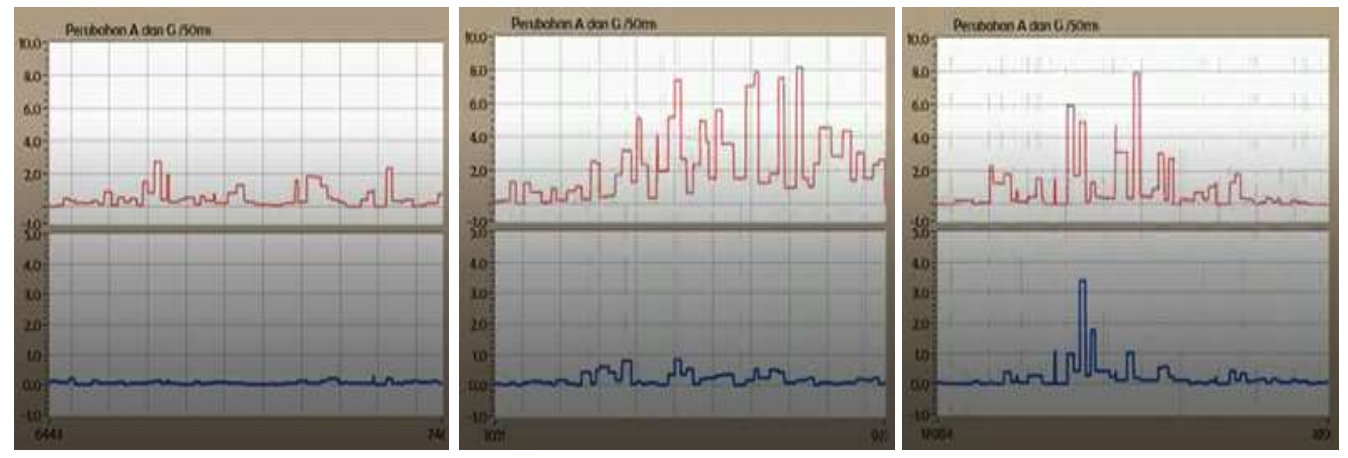

Gambar 10. Sinyal dari sensor (kiri ke kanan: aktifitas ringan, berat, gerak jatuh). Warna merah accelerometer dan biru gyroscope

Nilai threshold tersebut kemudian dijadikan acuan untuk menentukan range nilai setiap gerakan untuk membuat fuzifikasi, seperti di Tabel 2 berikut ini: 
Melita, dkk

Tabel 2. Range Nilai Setiap Gerakan

\begin{tabular}{|c|c|c|}
\hline \multicolumn{2}{|c|}{ Data masukan } & \multirow{2}{*}{ Jenis gerakan } \\
\hline Accelerometer (a) & Gyroscope (g) & \\
\hline $\begin{array}{c}a \leq 2 \\
1 \leq a \leq 3.7 \\
3 \leq a \leq 5.2 \\
a \geq 4.7\end{array}$ & $\begin{array}{c}\mathrm{g}<0.8 \\
0.5 \leq \mathrm{g} \leq 1.2 \\
1 \leq \mathrm{g} \leq 1.8 \\
\mathrm{~g} \geq 1.5\end{array}$ & $\begin{array}{c}\text { Istirahat } \\
\text { Aktifitas ringan } \\
\text { Aktifitas berat } \\
\text { Jatuh } \\
\end{array}$ \\
\hline
\end{tabular}

Setelah range nilai didapatkan, maka dilakukan pembuatan membership function input berupa kurva trapesium seperti pada Gambar 11 dan Gambar 12.

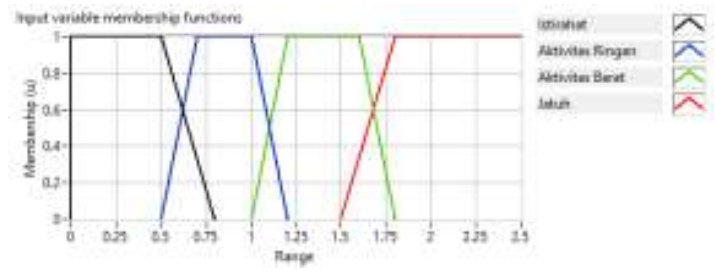

Gambar 11. Membership Function Input Accelerometer

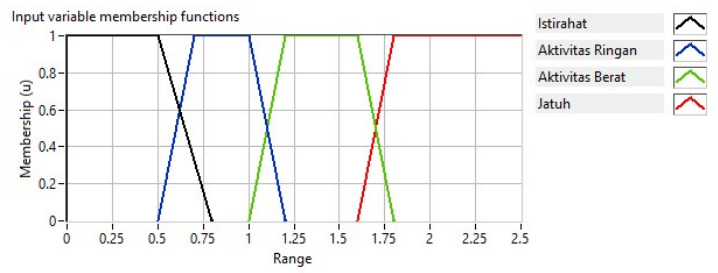

Gambar 12. Membership Function Input Gyroscope

Kedua input tersebut kemudian diolah untuk mendapatkan output dengan kategori istirahat, aktifitas ringan, aktifitas berat, dan jatuh seperti Gambar 13 berikut.

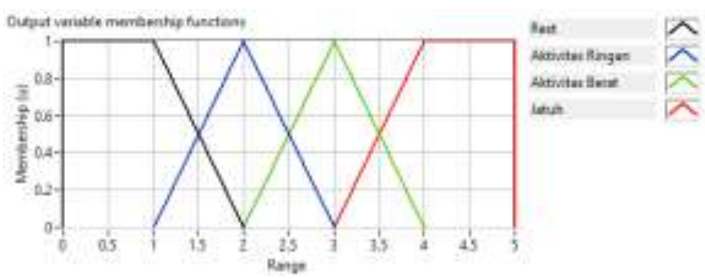

Gambar 13. Membership Function Output

Adapun aturan yang digunakan untuk mendapatkan output di atas adalah aturan fuzzy rule based IF-THEN. Sedangkan pada proses defuzifikasi digunakan metode AND yang menentukan output dari derajat membership dengan nilai persentase terbesar. Data sensor juga diolah untuk mengetahui posisi objek, dengan cara mengubah koordinat sensor menjadi koordinat navigasi. Penelitian ini mengusulkan modifikasi di data sensor yang berupa percepatan diintegralkan sebanyak dua kali untuk mendapatkan posisi, dan data kecepatan sudut diintegralkan satu kali untuk mendeteksi perubahan arah objek.

\subsection{Kendali motor}

Subsistem pengendali motor servo diawali dengan pengolahan data posisi dari subsistem sebelumnya. Pengolahan ini dilakukan untuk mendapatkan besar sudut putaran motor servo. Rumus yang digunakan untuk mendapatkan besar sudut dari data posisi adalah:

$$
\theta=\tan ^{-1} \frac{S y}{S x}
$$

Besar sudut yang didapatkan dikirim kepada arduino nano yang kemudian akan menggerakkan motor servo. Setelah motor servo bergerak mengarahkan kamera kepada objek, kamera akan diaktifkan untuk mengambil gambar objek dan kemudian gambar yang dihasilkan disimpan dan dikirim kepada pengguna atau perawat. 


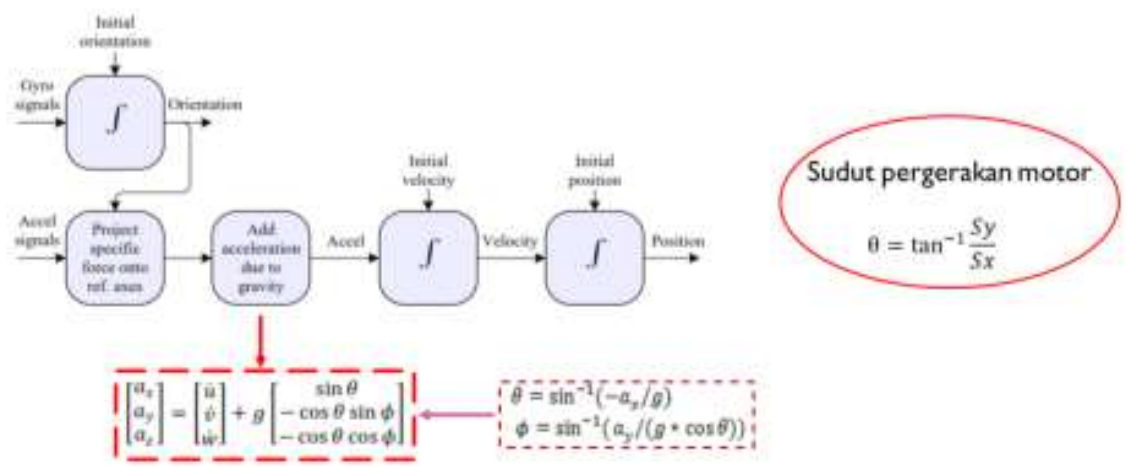

Gambar 14. Pergerakan Motor

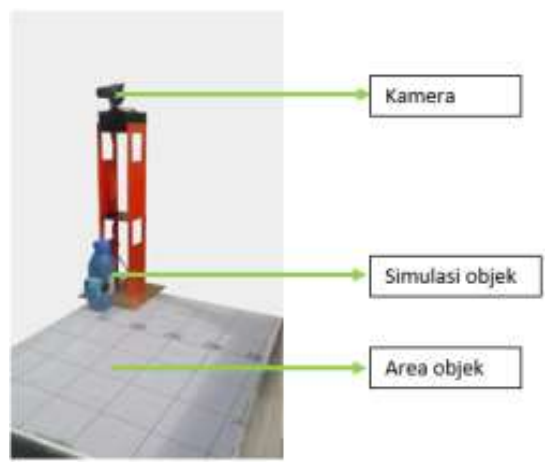

Pengujian sistem dilakukan dengan menggunakan sebuah pemodelan sistem. Gambar 15 berikut adalah pemodelan sistem pendeteksi jatuh dan penggerak kamera yang telah dibuat.

Gambar 15. Pemodelan Sistem

\subsection{Evaluasi}

Terdapat tiga pengujian yang dilakukan untuk mengetahui kesesuaian sistem dengan tujuan penelitian, yaitu:

1. Pengujian deteksi jenis gerakan

2. Pengujian pergerakan motor

3. Pengujian waktu respon

Penelitian pengendalian kamera berdasarkan deteksi posisi manusia bergerak jatuh berbasis sensor accelerometer dan gyroscope yang telah diintegrasikan terlihat pada Gambar 16 berikut.

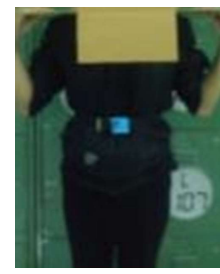

Gambar 16. (a) Implementasi Aktual Objek Manusia

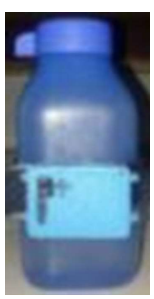

Gambar 16. (b) Implementasi Simulasi Objek Botol

Dari gambar di atas dapat dilihat bahwa terdapat dua objek dalam melakukan pengujian. Adapun metoda dan hasil pengujian ditunjukan sebagai berikut: 


\subsubsection{Pengujian deteksi jenis gerakan}

Pengujian ini dilakukan untuk mengetahui kemampuan sistem dalam mendeteksi gerakan objek. Penelitian ini dilakukan dengan metode confusion matrix, dimana metode ini membagi hasil pengujian menjadi 4 kondisi umum, yaitu:

1. TP (true positive): ketika kondisi aktual jatuh dan sistem mendeteksi jatuh.

2. TN (true negative): ketika kondisi aktual tidak jatuh dan sistem mendeteksi tidak jatuh.

3. FP (false positive): ketika kondisi aktual tidak jatuh dan sistem mendeteksi jatuh.

4. FN (false negative): ketika kondisi aktual jatuh dan sistem mendeteksi tidak jatuh.

Dari 4 kondisi di atas, nilai recall (true positive rate), specificity (true negative rate), precision (ketelitian saat mendeteksi jatuh), dan accuracy (ketepatan dalam mendeteksi) sistem dapat diketahui. Berikut adalah persamaan yang digunakan untuk menghitung nilainilai tersebut (Han, Kamber, \& Pei, 2011):

$$
\begin{gathered}
\text { Recall }(T P R)=\frac{T P}{T P+F N} \\
\text { Specificity }(T N R)=\frac{T N}{T N+F P} \\
\text { Precision }=\frac{T P}{T P+F P} \\
\text { Accuracy }=\frac{T P+T N}{T P+F P+F N+T N}
\end{gathered}
$$

Pengujian deteksi gerak ini dilakukan dengan beberapa skenario jatuh untuk mengetahui recall (kemampuan deteksi jatuh), specificity (kemampuan deteksi aktifitas biasa), precision (ketelitian saat mendeteksi jatuh), dan accuracy (ketepatan dalam mendeteksi) sistem dalam mendeteksi gerakan yang dilakukan objek.

\section{Pengujian deteksi gerak aktual (objek manusia)}

Pengujian deteksi gerak dibagi menjadi beberapa skenario.

Tabel 3. Pengujian Deteksi Gerak Aktual (Objek Manusia)

\begin{tabular}{ccccc}
\hline No & Aktual & Sistem & Keterangan & Foto Skenario 1 \\
\hline 1 & Jatuh & Jatuh & TP & \\
2 & Jatuh & Jatuh & TP & \\
3 & Jatuh & Jatuh & TP & \\
4 & Jatuh & Jatuh & TP & \\
5 & Jatuh & Jatuh & TP & \\
6 & Jatuh & Tidak jatuh & FN & \\
7 & Jatuh & Jatuh & TP & \\
8 & Jatuh & Tidak jatuh & FN & Foto Skenario 2 \\
9 & Jatuh & Jatuh & TP & \\
10 & Jatuh & Tidak jatuh & FN & \\
\hline No & Aktual & Sistem & Keterangan & \\
\hline 1 & Jatuh & Jatuh & TP & \\
2 & Jatuh & Jatuh & TP & \\
3 & Jatuh & Jatuh & TP & \\
4 & Jatuh & Jatuh & TP & \\
5 & Jatuh & Jatuh & TP & \\
6 & Jatuh & Jatuh & TP & \\
7 & Jatuh & Jatuh & TP & \\
8 & Jatuh & Jatuh & TP & \\
9 & Jatuh & Tidak jatuh & FN & \\
10 & Jatuh & Jatuh & TP & \\
\hline
\end{tabular}




\section{Tabel 4. Pengujian Deteksi Gerak Aktual (Objek Manusia) (Lanjutan)}

\begin{tabular}{ccccc|}
\hline No & Aktual & Sistem & Keterangan & Foto Skenario 3 \\
\hline 1 & Jatuh & Jatuh & TP & \\
2 & Jatuh & Tidak jatuh & FN & \\
3 & Jatuh & Jatuh & TP & \\
4 & Jatuh & Jatuh & TP & \\
5 & Jatuh & Jatuh & TP & \\
6 & Jatuh & Jatuh & TP & \\
7 & Jatuh & Jatuh & TP & Foto Skenario 4 \\
8 & Jatuh & Jatuh & TP & \\
9 & Jatuh & Jatuh & TP & \\
10 & Jatuh & Tidak jatuh & FN & \\
\hline No & Aktual & Sistem & Keterangan & \\
\hline 1 & Jatuh & Jatuh & TP & \\
2 & Jatuh & Jatuh & TP & \\
3 & Jatuh & Jatuh & TP & \\
4 & Jatuh & Jatuh & TP & \\
5 & Jatuh & Tidak Jatuh & FN & \\
6 & Jatuh & Jatuh & TP & \\
7 & Jatuh & Jatuh & TP & \\
8 & Jatuh & Tidak jatuh & FN & \\
9 & Jatuh & Jatuh & TP & \\
10 & Jatuh & Jatuh & TP &
\end{tabular}

Total pengujian adalah 60 kali. Kondisi umum pendeteksian yang didapatkan adalah true positive (TP) sebanyak 32 kali, true negative (TN) sebanyak 17 kali, false positive (FP) sebanyak 3 kali, dan false negative (FN) sebanyak 8 kali. Evaluasi yang didapatkan adalah recall sebesar $80 \%$, specificity sebesar $85 \%$, precision sebesar $91 \%$, dan accuracy sebesar $82 \%$.

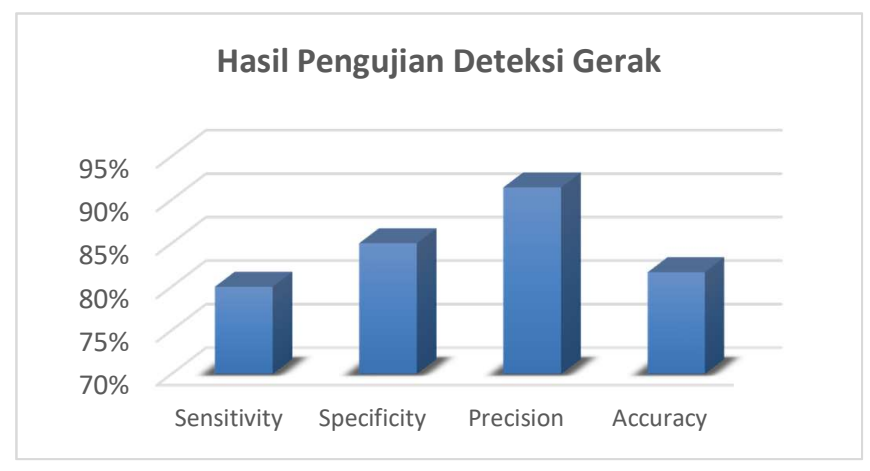

Gambar 17. Grafik Hasil Pengujian Deteksi Gerak pada Manusia

\section{Pengujian deteksi gerak simulasi (objek botol)}

Pengujian deteksi gerak dengan beberapa scenario seperti yang ditunjukan pada Tabel 5 
Tabel 5. Pengujian Deteksi Gerak Simulasi (Objek Botol)

\begin{tabular}{|c|c|c|c|c|}
\hline No & Aktual & Sistem & Keterangan & Foto Skenario 1 \\
\hline 1 & Jatuh & Jatuh & $\mathrm{TP}$ & \\
\hline 2 & Jatuh & Jatuh & TP & \\
\hline 3 & Jatuh & Jatuh & TP & \\
\hline 4 & Jatuh & Jatuh & TP & \\
\hline 5 & Jatuh & Jatuh & TP & \\
\hline 6 & Jatuh & Jatuh & TP & \\
\hline 7 & Jatuh & Jatuh & TP & \\
\hline 8 & Jatuh & Tidak jatuh & FN & \\
\hline 9 & Jatuh & Jatuh & TP & \\
\hline 10 & Jatuh & Jatuh & TP & \\
\hline No & Aktual & Sistem & Keterangan & Foto Skenario 2 \\
\hline 1 & Jatuh & Jatuh & TP & \\
\hline 2 & Jatuh & Jatuh & TP & \\
\hline 3 & Jatuh & Jatuh & TP & \\
\hline 4 & Jatuh & Jatuh & TP & \\
\hline 5 & Jatuh & Jatuh & TP & \\
\hline 6 & Jatuh & Jatuh & TP & \\
\hline 7 & Jatuh & Jatuh & TP & \\
\hline 8 & Jatuh & Jatuh & TP & \\
\hline 9 & Jatuh & Jatuh & TP & \\
\hline 10 & Jatuh & Jatuh & TP & \\
\hline No & Aktual & Sistem & Keterangan & Foto Skenario 3 \\
\hline 1 & Jatuh & Jatuh & $\mathrm{TP}$ & \\
\hline 2 & Jatuh & Tidak jatuh & FN & \\
\hline 3 & Jatuh & Jatuh & TP & \\
\hline 4 & Jatuh & Jatuh & TP & \\
\hline 5 & Jatuh & Jatuh & TP & \\
\hline 6 & Jatuh & Jatuh & TP & \\
\hline 7 & Jatuh & Jatuh & TP & \\
\hline 8 & Jatuh & Jatuh & TP & \\
\hline 9 & Jatuh & Jatuh & TP & \\
\hline 10 & Jatuh & Jatuh & TP & \\
\hline No & Aktual & Sistem & Keterangan & Foto Skenario 4 \\
\hline 1 & Jatuh & Jatuh & TP & \\
\hline 2 & Jatuh & Jatuh & TP & \\
\hline 3 & Jatuh & Jatuh & TP & \\
\hline 4 & Jatuh & Jatuh & TP & \\
\hline 5 & Jatuh & Jatuh & TP & \\
\hline 6 & Jatuh & Jatuh & TP & pt \\
\hline 7 & Jatuh & Jatuh & TP & \\
\hline 8 & Jatuh & Jatuh & TP & \\
\hline 9 & Jatuh & Jatuh & TP & \\
\hline 10 & Jatuh & Jatuh & TP & \\
\hline
\end{tabular}


Jumlah pengujian pada botol sama dengan pengujian yang dilakukan pada manusia. Kondisi umum pendeteksian yang didapatkan dari pengujian ini adalah true positive (TP) sebanyak 38 kali, true negative (TN) sebanyak 18 kali, false positive (FP) sebanyak 2 kali, dan false negative (FN) sebanyak 2 kali. Dari kondisi umum tersebut didapatkan recall sebesar 95\%, specificity sebesar 90\%, precision sebesar 95\%, dan accuracy sebesar $93 \%$.

\subsubsection{Pengujian pergerakan motor}

Pengujian ini dilakukan untuk mengetahui ketepatan sistem dalam mendeteksi posisi objek. Pergerakan motor dikatakan berhasil jika seluruh badan objek ada pada gambar yang diambil seperti Gambar 19 berikut.

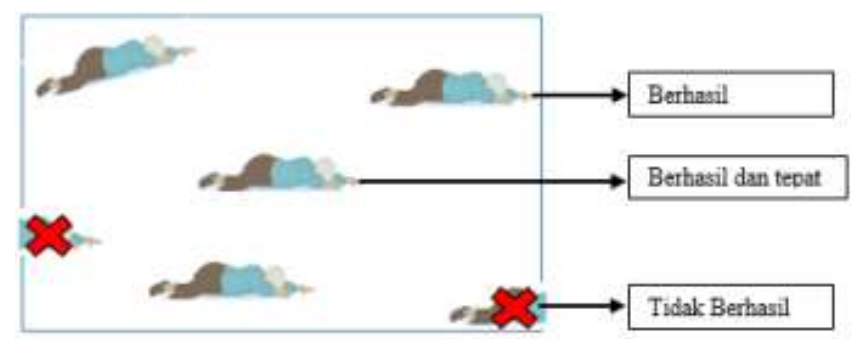

Gambar 19. Posisi Objek pada Gambar

Berdasarkan Gambar 19 dapat dilihat bahwa jika badan objek hanya setengah pada gambar yang diambil oleh kamera, pergerakan motor ke arah objek dianggap tidak berhasil. Namun jika objek berada di tengah-tengah frame gambar, pergerakan motor dianggap berhasil dan tepat.

Pengujian gerakan motor ini dilakukan dengan beberapa skenario perpindahan untuk mengetahui tingkat keberhasilan kamera untuk mendapatkan gambar objek (precision) dan untuk mengetahui ketepatan pergerakan motor dalam mendeteksi posisi.

\section{Pengujian gerakan motor aktual (objek manusia)}

Pengujian gerakan motor dengan beberapa scenario ditunjukan pada Tabel 6 . 
Tabel 6. Pengujian Gerakan Motor Aktual (Objek Manusia)

\begin{tabular}{|c|c|c|c|c|c|c|c|c|}
\hline \multicolumn{9}{|c|}{ Skenario 1} \\
\hline \multirow{2}{*}{ No } & \multirow{2}{*}{$\begin{array}{l}\text { Gambar } \\
\text { berhasil }\end{array}$} & \multirow{2}{*}{ Precission } & \multicolumn{2}{|c|}{ Sudut } & \multirow{2}{*}{$\begin{array}{c}\text { Error } \\
\text { sudut } \\
(\%)\end{array}$} & \multicolumn{2}{|c|}{$\begin{array}{c}\text { Posisi pada } \\
\text { gambar (pixel) }\end{array}$} & \multirow{2}{*}{$\begin{array}{c}\text { Error } \\
\text { posisi } \\
(\%)\end{array}$} \\
\hline & & & Aktual & Sistem & & Aktual & Sistem & \\
\hline 1 & $\mathrm{Ya}$ & \multirow{10}{*}{$80 \%$} & 23 & 37 & 61 & \multirow{10}{*}{320} & 576 & 80 \\
\hline 2 & $\mathrm{Ya}$ & & 23 & 22 & 4 & & 483 & 51 \\
\hline 3 & Tidak & & 20.5 & 73 & 25 & & 0 & 100 \\
\hline 4 & $\mathrm{Ya}$ & & 7 & 2 & 71 & & 300 & 6 \\
\hline 5 & $\mathrm{Ya}$ & & 8 & 20 & 15 & & 403 & 26 \\
\hline 6 & $\mathrm{Ya}$ & & 9.5 & 15 & 58 & & 325 & 2 \\
\hline 7 & $\mathrm{Ya}$ & & 9.5 & 1 & 89 & & 236 & 26 \\
\hline 8 & $\mathrm{Ya}$ & & 7 & 3 & 57 & & 408 & 28 \\
\hline 9 & $\mathrm{Ya}$ & & 7 & 5 & 29 & & 387 & 21 \\
\hline 10 & Tidak & & 0 & 68 & 100 & & 0 & 100 \\
\hline
\end{tabular}

Skenario 2

\begin{tabular}{|c|c|c|c|c|c|c|c|c|}
\hline \multirow{2}{*}{ No } & \multirow{2}{*}{$\begin{array}{l}\text { Gambar } \\
\text { berhasil }\end{array}$} & \multirow{2}{*}{ Precission } & \multicolumn{2}{|c|}{ Sudut } & \multirow{2}{*}{$\begin{array}{c}\text { Error } \\
\text { sudut } \\
(\%)\end{array}$} & \multicolumn{2}{|c|}{$\begin{array}{c}\text { Posisi pada } \\
\text { gambar (pixel) }\end{array}$} & \multirow{2}{*}{$\begin{array}{c}\text { Error } \\
\text { posisi } \\
(\%)\end{array}$} \\
\hline & & & Aktual & Sistem & & Aktual & Sistem & \\
\hline 1 & $\mathrm{Ya}$ & \multirow{10}{*}{$80 \%$} & 80 & 67 & 16 & \multirow{10}{*}{320} & 395 & 23 \\
\hline 2 & $\mathrm{Ya}$ & & 81 & 78 & 4 & & 499 & 56 \\
\hline 3 & $\mathrm{Ya}$ & & 82 & 71 & 13 & & 378 & 18 \\
\hline 4 & Tidak & & 84 & 47 & 44 & & 0 & 100 \\
\hline 5 & Tidak & & 77 & 82 & 6 & & 0 & 100 \\
\hline 6 & $\mathrm{Ya}$ & & 83 & 72 & 13 & & 371 & 16 \\
\hline 7 & $\mathrm{Ya}$ & & 83 & 70 & 16 & & 313 & 2 \\
\hline 8 & $\mathrm{Ya}$ & & 84 & 61 & 27 & & 200 & 38 \\
\hline 9 & $\mathrm{Ya}$ & & 83 & 55 & 34 & & 141 & 56 \\
\hline 10 & Ya & & 80.5 & 88 & 9 & & 570 & 78 \\
\hline
\end{tabular}

Skenario 3

\begin{tabular}{|c|c|c|c|c|c|c|c|c|}
\hline \multirow{2}{*}{ No } & \multirow{2}{*}{$\begin{array}{l}\text { Gambar } \\
\text { berhasil }\end{array}$} & \multirow{2}{*}{ Precission } & \multicolumn{2}{|c|}{ Sudut } & \multirow{2}{*}{$\begin{array}{c}\text { Error } \\
\text { sudut } \\
(\%)\end{array}$} & \multicolumn{2}{|c|}{$\begin{array}{c}\text { Posisi pada } \\
\text { gambar (pixel) }\end{array}$} & \multirow{2}{*}{$\begin{array}{c}\text { Error } \\
\text { posisi } \\
(\%)\end{array}$} \\
\hline & & & Aktual & Sistem & & Aktual & Sistem & \\
\hline 1 & Ya & \multirow{10}{*}{$80 \%$} & 63 & 59 & 6 & \multirow{10}{*}{320} & 273 & 15 \\
\hline 2 & Ya & & 63 & 52 & 17 & & 195 & 39 \\
\hline 3 & $\mathrm{Ya}$ & & 59 & 50 & 15 & & 262 & 18 \\
\hline 4 & Tidak & & 50 & 7 & 86 & & 0 & 100 \\
\hline 5 & Tidak & & 63 & 15 & 76 & & 0 & 100 \\
\hline 6 & Ya & & 53 & 53 & 0 & & 241 & 25 \\
\hline 7 & Ya & & 63 & 71 & 13 & & 429 & 34 \\
\hline 8 & $Y a$ & & 56 & 28 & 50 & & 227 & 29 \\
\hline 9 & $\mathrm{Ya}$ & & 51 & 26 & 49 & & 185 & 42 \\
\hline 10 & Ya & & 60 & 43 & 28 & & 211 & 34 \\
\hline
\end{tabular}


Tabel 7. Pengujian Gerakan Motor Aktual (Objek Manusia) (Lanjutan)

Skenario 4

\begin{tabular}{|c|c|c|c|c|c|c|c|c|}
\hline \multirow{2}{*}{ No } & \multirow{2}{*}{$\begin{array}{l}\text { Gambar } \\
\text { berhasil }\end{array}$} & \multirow{2}{*}{ Precission } & \multicolumn{2}{|c|}{ Sudut } & \multirow{2}{*}{$\begin{array}{c}\text { Error } \\
\text { sudut } \\
(\%)\end{array}$} & \multicolumn{2}{|c|}{$\begin{array}{c}\text { Posisi pada } \\
\text { gambar (pixel) }\end{array}$} & \multirow{2}{*}{$\begin{array}{c}\text { Error } \\
\text { posisi } \\
(\%)\end{array}$} \\
\hline & & & Aktual & Sistem & & Aktual & Sistem & \\
\hline 1 & $\mathrm{Ya}$ & \multirow{10}{*}{$90 \%$} & 54 & 87 & 61 & \multirow{10}{*}{320} & 594 & 80 \\
\hline 2 & Ya & & 56 & 74 & 32 & & 457 & 43 \\
\hline 3 & Ya & & 58 & 30 & 48 & & 158 & 51 \\
\hline 4 & $\mathrm{Ya}$ & & 58 & 83 & 43 & & 514 & 61 \\
\hline 5 & Ya & & 45 & 75 & 67 & & 445 & 39 \\
\hline 6 & Ya & & 73 & 57 & 22 & & 108 & 66 \\
\hline 7 & Ya & & 63 & 73 & 16 & & 451 & 41 \\
\hline 8 & Tidak & & 33 & 87 & 16 & & 0 & 100 \\
\hline 9 & Ya & & 63 & 78 & 24 & & 437 & 37 \\
\hline 10 & $\mathrm{Ya}$ & & 60 & 82 & 37 & & 470 & 47 \\
\hline \multicolumn{9}{|c|}{ Skenario 5} \\
\hline \multirow{2}{*}{ No } & \multirow{2}{*}{$\begin{array}{l}\text { Gambar } \\
\text { berhasil }\end{array}$} & \multirow{2}{*}{ Precission } & \multicolumn{2}{|c|}{ Sudut } & $\begin{array}{l}\text { Error } \\
\text { sudut }\end{array}$ & \multicolumn{2}{|c|}{$\begin{array}{c}\text { Posisi pada } \\
\text { gambar (pixel) }\end{array}$} & $\begin{array}{l}\text { Error } \\
\text { posisi }\end{array}$ \\
\hline & & & Aktual & Sistem & $(\%)$ & Aktual & Sistem & $(\%)$ \\
\hline 1 & $\mathrm{Ya}$ & \multirow{10}{*}{$70 \%$} & 38 & 57 & 50 & \multirow{10}{*}{320} & 329 & 3 \\
\hline 2 & $\mathrm{Ya}$ & & 58 & 53 & 9 & & 217 & 32 \\
\hline 3 & Tidak & & 31 & 83 & 16 & & 0 & 100 \\
\hline 4 & $\mathrm{Ya}$ & & 51 & 23 & 55 & & 305 & 5 \\
\hline 5 & $\mathrm{Ya}$ & & 78 & 83 & 6 & & 395 & 23 \\
\hline 6 & Tidak & & 26 & 73 & 18 & & 0 & 100 \\
\hline 7 & $\mathrm{Ya}$ & & 60 & 48 & 20 & & 189 & 41 \\
\hline 8 & Tidak & & 26 & 77 & 196 & & 0 & 100 \\
\hline 9 & $\mathrm{Ya}$ & & 76 & 29 & 62 & & 96 & 70 \\
\hline 10 & Ya & & 26 & 22 & 15 & & 289 & 10 \\
\hline
\end{tabular}

Dari tabel-tabel di atas dapat dilihat bahwa total pengujian adalah 50 kali. Dari pengujian tersebut didapatkan tingkat keberhasilan kamera dalam mendapatkan gambar objek yang terdeteksi jatuh adalah sebesar $80 \%$, error pergerakan motor dari perhitungan sudut posisi objek adalah $54 \%$ dan dari perhitungan posisi objek pada gambar adalah $48 \%$.

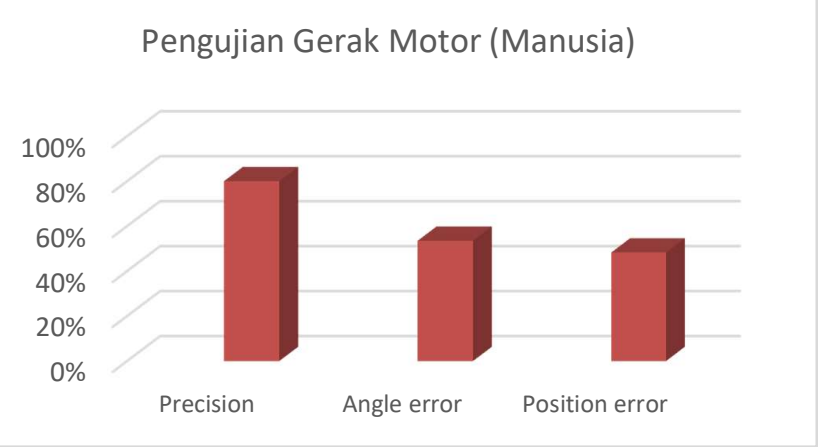

Gambar 20. Grafik Hasil Pengujian Gerak Motor Pada Manusia

\section{Pengujian gerakan motor simulasi (objek botol)}

Jumlah pengujian pada botol sama dengan pengujian yang dilakukan pada manusia. Hasil pengujian didapatkan tingkat keberhasilan kamera dalam mendapatkan gambar objek yang terdeteksi jatuh adalah sebesar $92 \%$, error pergerakan motor dari perhitungan sudut posisi objek adalah $49 \%$ dan dari perhitungan posisi objek pada gambar adalah $44 \%$. 


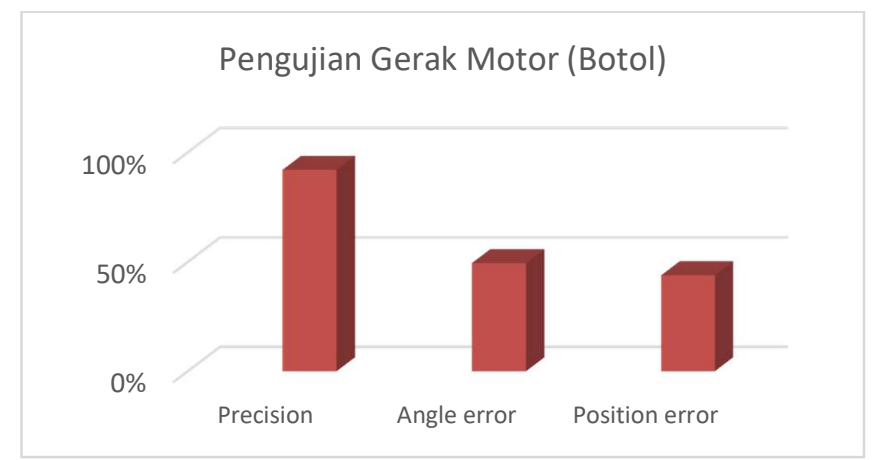

Gambar 21. Grafik Hasil Pengujian Gerak Motor Pada Botol

\subsubsection{Pengujian waktu respon}

Pengujian ini dilakukan untuk mengetahui waktu proses pengiriman notifikasi saat objek terdeteksi jatuh. Waktu mulai dihitung setelah sistem mendeteksi adanya aktifitas jatuh dan berhenti setelah email berhasil dikirimkan kepada pengawas. Pengujian ini dilakukan menggunakan timer yang ada pada Labview.

Hasil dari pengujian waktu respon sistem dapat dilihat pada Gambar 22 berikut.

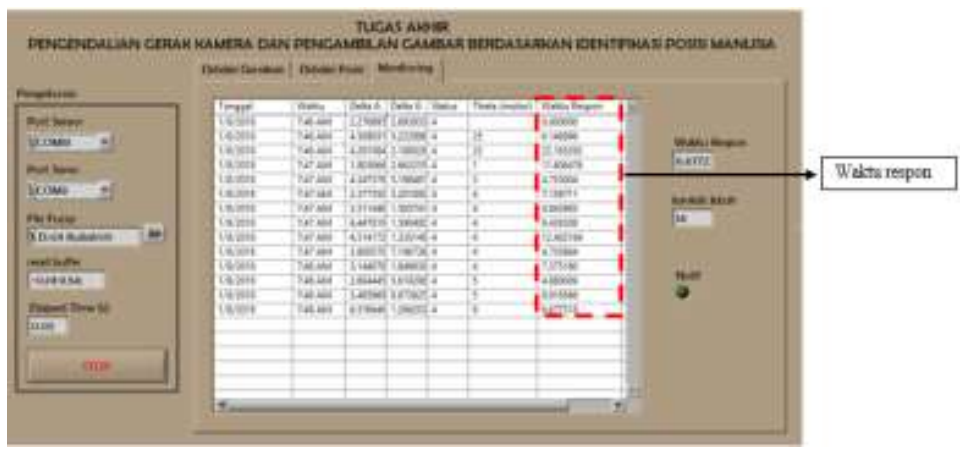

Gambar 22. Waktu Respon Sistem

Berdasarkan data di atas, waktu respon sistem yang paling cepat adalah 4,7 detik dan yang paling lama adalah 22,2 detik. Perbedaan kecepatan respon ini dipengaruhi oleh besar sudut pergerakan motor, kecepatan respon kamera, sinyal internet yang digunakan untuk mengirim email, serta kecepatan respon dari PC yang digunakan. Tampilan notifikasi yang diterima oleh pengawas dapat dilihat pada Gambar 23, sedangkan format email yang dikirimkan dapat dilihat pada Gambar 24.

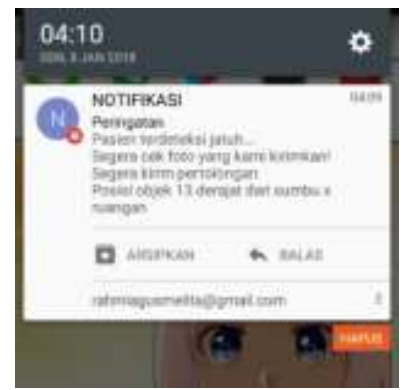

Gambar 23. Notifikasi yang Dikirimkan kepada Pengawas

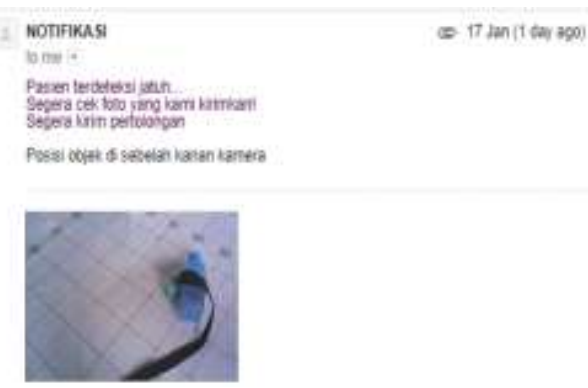

Gambar 24. Format Email yang Dikirimkan kepada Pengawas 
Pengendalian Kamera berdasarkan Deteksi Posisi Manusia Bergerak Jatuh Berbasis Multisensor Accelerometer dan Gyroscope

\section{KESIMPULAN}

Pengujian deteksi gerak yang telah dilakukan mendapatkan nilai keluaran dari pengujian yang dilakukan baik pada manusia maupun pada botol didapatkan nilai recall sebesar $88 \%$, specificity sebesar $88 \%$, precision sebesar $93 \%$, dan accuracy sebesar $88 \%$. Dari nilai tersebut dapat disimpulkan bahwa sistem bekerja dengan baik. Adapun kesalahan pendeteksian yang terjadi pada sistem disebabkan oleh tingkat kekerasan benturan yang terjadi saat objek terjatuh dan besar percepatan dari aktifitas tertentu yang sama dengan percepatan saat kondisi jatuh. Sedangkan pengujian gerakan motor yang telah dilakukan mendapatkan nilai keluaran dari dua pengujian ini didapatkan keberhasilan dalam mengambil gambar sebesar $86 \%$ dan ketepatan pergerakan motor sebesar $51 \%$. Dari nilai tersebut dapat disimpulkan bahwa sistem dapat mengambil gambar objek yang terdeteksi jatuh dengan baik, namun tidak tepat. Sedangkan ketidaktepatan pergerakan motor dipengaruhi oleh nilai yang dihasilkan sensor.

\section{DAFTAR RUJUKAN}

N, Y., Z, W., Gravina, R., \& Fortino, G. (2017). A survey of open body sensor networks: Applications and challenges. In 14th IEEE Annual Consumer Communications \& Networking Conference (CCNC) (hal. 65-70). Las Vegas, NV. http://doi.org/10.1109/CCNC.2017.7983083

Nur Arifin, D., Wibisono, W., \& Adi Pratomo, B. (2013). Rancang Bangun Sistem Fall Detection untuk Pengguna Bergerak Berbasis Sensor Accelerometer dan Sensor Gyroscope pada Perangkat Mobile. Jurnal Teknik POMITS, 2(1), 1-4.

Hardjianto, M., Rony, M. A., \& Trengginas, G. S. (2016). Deteksi jatuh pada lansia dengan menggunakan akselerometer pada smartphone. Prosiding SENTIA (pp. 284-288).

Tang, A. Y. C., Ong, C.-H., \& Ahmad, A. (2015). Fall Detection Sensor System for the Elderly. International Journal of Advanced Computer Research, 5, 176-183.

Wasis, I., Kurniawan, W., \& Muttaqin, A. (2015). Deteksi Jatuh pada Manula di Rumah Menggunakan Sensor Akselerometer dan Kamera. Jurnal Mahasiswa PTIIK UB.

Hidayatno, A., \& Wahyudi. (2011). Rancang Bangun Inertial Measurement Unit Sebagai Sistem Monitoring Kendaraan Bergerak Berbasis Sensor Accelerometer dan Gyroscope. Jurnal Rekayasa Elektrika Vol, 9(4), 187-194.

Perkasa, T., \& Rachmat, H. H. (2017). Perancangan Alat Ukur Sudut Tekuk Lutut Wireless menggunakan Sensor Gyroscope berbasis ATMega 328 dan ATMega 2560. ELKOMIKA: Jurnal Teknik Energi Elektrik, Teknik Telekomunikasi, \& Teknik Elektronika, 5(1), 30 47.

Han, J., Kamber, M., \& Pei, J. (2011). Data Mining: Concepts and Techniques (3rd ed.). San Francisco, CA, USA: Morgan Kaufmann Publishers Inc. 